\title{
A Study on the Theories' Gap of Technological Entrepreneurship Opportunities Emergence
}

\author{
Behrooz Jamali ${ }^{1}$, Reza MohammadKazemi ${ }^{2}$, Jahangir Yadollahi Farsi ${ }^{3}$, Ali Mobini Dehkordi ${ }^{2}$ \\ ${ }^{1} \mathrm{PhD}$ Candidate in Entrepreneurship, Faculty of Entrepreneurship, University of Tehran, Tehran, Iran \\ ${ }^{2}$ Associate Professor \& Head of Business Department, Faculty of Entrepreneurship, University of Tehran, Tehran, \\ Iran \\ ${ }^{3}$ Faculty Member \& Deputy for Academic Affairs and Graduate Studies, Faculty of Entrepreneurship, University \\ of Tehran, Tehran, Iran
}

Correspondence: Reza MohammadKazemi, Associate Professor \& Head of Business Department, Faculty of Entrepreneurship, University of Tehran, Tehran, Iran.

Received: September 29, 2017

doi:10.5539/ibr.v11n2p79
Accepted: December 29, 2017 Online Published: January 8, 2018

URL: https://doi.org/10.5539/ibr.v11n2p79

\begin{abstract}
Many believe that traditional models and traditional theories of identifying and exploiting opportunities in such situations do not have the required efficiency since they act linearly and require nonlinear models to identify and exploit these opportunities. Henceforth, adapting compatible and innovative strategies are necessary to meet the changing needs of customers as well as environmental uncertainties. In this research, while studying existing theories about technological entrepreneurship opportunities, a theoretical gap was studied. The study showed that there are several questions that have not been addressed in existing theories and more research should be done to answer these questions and to fill the theories gap.
\end{abstract}

Keywords: technological entrepreneurial opportunities, opportunities emergence, theories' gap

\section{Introduction}

In purpose of taking the advantages of the business opportunities emergence and to remain in the realm of competition, companies are forced to remain in the creating theory that the end of the evolutionary enactment cannot be considered from the beginning. In this regard, it can be argued that future opportunities are not related to existing information and therefore it is necessary to create new knowledge and information. In this situation, it is impossible to predict the probable outcome of the formation and exploitation of entrepreneurial opportunities, as well as, the probability of occurrence of those outcomes are unpredictable. This situation is similar to the definition of uncertainty, which was first proposed by Knight (1921). Creation theory is used to describe the formation and exploitation of entrepreneurial opportunities in which entrepreneurs are in a state of Knightian uncertainty or indecision (Alvarez \& Barney, 2005), and there is no knowledge of the opportunity. The evidence of this is an investigation of research and development projects and business plans failures that arise from the mismatch of predictions with the actual events that take place in the future, and this issue is due to the unpredictability of many of the anomalies and phenomena of society. Therefore, past processes and mechanisms are not responsive to new phenomena due to current rapid changes.

On the other hand, in anticipation of opportunities that are in the context of Knightian uncertainty, there is no room for prediction. According to Sarasvathy (2008), entrepreneurs, in anticipation of opportunities that are in uncertain conditions, instead of anticipating, organize to control process according to available facilities, and by receiving feedback from the information environment, modifying or tracking their goals. Under uncertainty, entrepreneurs follow the decision logic that is different from traditional and logical entrepreneurial models (Sarasvathy, 2008).

Many believe that traditional models and theories of identifying and exploiting opportunities in such situations do not have the required efficiency for the reason that they work linearly and nonlinear models are needed to identify and exploit these opportunities. Hence, adopting inno vative and compatible strategies are necessary to respond to the rapid changes in customer needs as well as environmental uncertainties. These days, regarding the rapid technological changes, we have discovered and created many opportunities, among which the creating 
opportunities have formed great value, for example, eBay 1.3 billion dollars, Yahoo 3.18 billion dollars, Facebook 33 billion dollars, WhatsApp 22 billion dollars. These statistics show the importance of emerging opportunities through entrepreneurial actions (Alimadadi et al., 2018). In the present research, the concept and theories of technological entrepreneurship opportunities have been investigated and the gap between existing theories has been studied based on previous studies.

\section{Technological Entrepreneurial Opportunities}

Wood and McKinley (2010) present a conceptual model of the production of entrepreneurial opportunities with a constructivist approach that assumes that the process of constructing opportunities involves various stages, including the conceptualization of an idea, objectification of the idea and approving the idea of a new business by an entrepreneur. All ideas will not survive in these stages. Between the stage of conceptualization and objectivity, some ideas are abandoned intended for lacking objectivity. Also, between the stage of objectification and approval, some of the opportunities are left out due to the insufficient support of resources (Wood and McKinley, 2010).

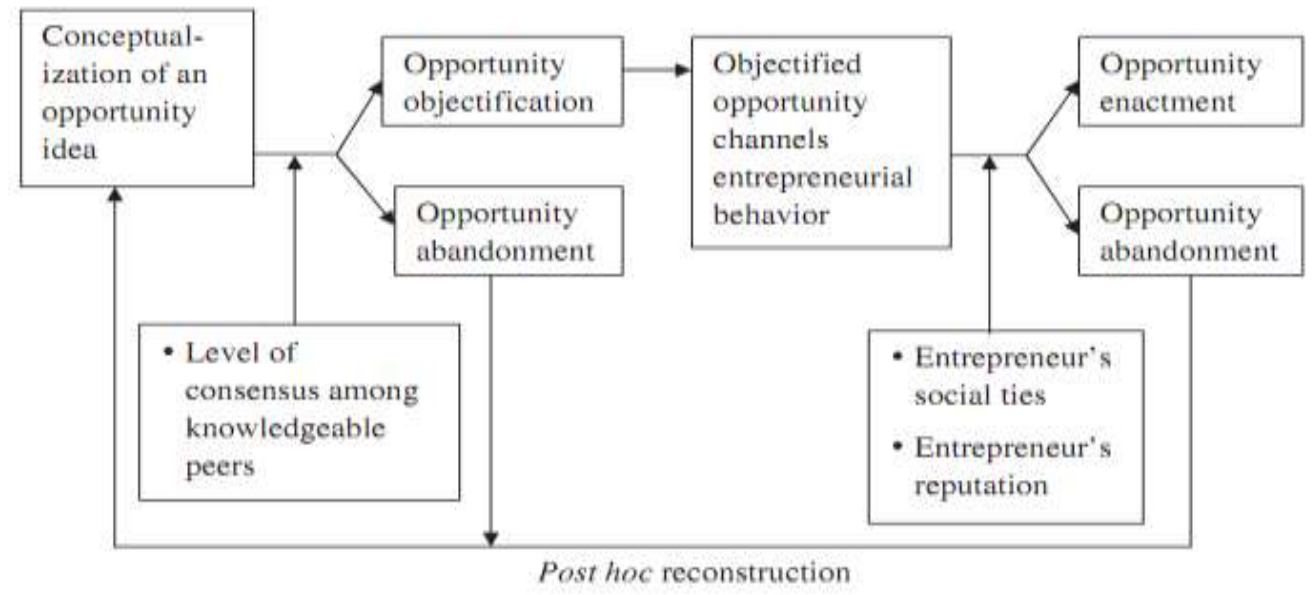

Figure 1. Opportunity creation process (Wood and McKinley, 2010)

In this process, opportunities arise when the entrepreneur, through the social world, has a cognitive assessment of reality. This process starts from an early idea in the entrepreneur's mind (Wood and McKinley, 2010).

\subsection{Process of Objectivity of an Opportunity}

In the stage of objectivity, the entrepreneur participates in a meaningful process. In this process, the entrepreneur tests the profitability of his initial idea by interacting with his counterparts, such as friends, family members, coaches and other people who have close ties with the entrepreneur and those who trust the entrepreneur. This step is due to uncertainty about the ability to profitability and the entrepreneur chooses their counterparts for access and trust. In the meantime, not all peers share the same value, but peers who have more knowledge, their beliefs give them more weight in objectivity. The objectivity stage transforms the idea into an objective opportunity, which is the quality of a foreign reality, for the entrepreneur. The greater the agreement between well-informed counterparts about the profitability of an idea, the greater likelihood of an entrepreneur's opportunity, and thus more entrepreneurial action (Wood and McKinley, 2010).

\subsection{Process of Adopting the Opportunity}

At this stage, ideas that have become an objective opportunity in the stage of objectivity may lead to an opportunity adopting level. At this point, the entrepreneur begins to participate in focused efforts to examine the likelihood of attracting resources for investment in time. This stage involves active participation in the social environment and bringing together a group of stakeholders that is wider than the group of counterparts in the previous phase. The entrepreneur strives to attract stakeholders to a future approach and ultimately reaches a common understanding of it, including an ongoing process including negotiating with potential investors, getting in touch with potential employees, examining potential clients, and Searching for required technology. With this exertion, the entrepreneur receives feedback from the stakeholders that will help him improve the next steps to influence on stakeholders. If common understanding between stakeholders is developed, the objectivity of opportunity for entrepreneurs and stakeholders will be strengthened. The constructivists believe that at the stage of adoption, the knowledge and beliefs of the external actors are influenced by the entrepreneur and vice versa. In general, the adoption of the opportunity is a social and cognitive process that, by bringing stakeholders into 
objectivity of opportunity, the entrepreneurial project becomes an objective opportunity for exploitation (Wood and McKinley, 2010)

\subsection{Entrepreneur in the Process of Producing Ideas}

Wood and McKinley (2010) indicate the importance of social ties and fame at the stage of adapting opportunity. By increasing social ties, access to stakeholders will be enhanced, which will facilitate the attraction of financial resources and human resource. Entrepreneur's reputation has also led to a decline in stakeholders' uncertainty about the successful adoption of an objective opportunity. In other words, fame leads to a positive signal to the stakeholders about the appropriateness of adoption of an opportunity (Wood and McKinley, 2010).

\section{The process of the Emergence of Technological Entrepreneurship Opportunities}

\subsection{Process Approach}

The approach currently addressed in entrepreneurship literature is a process approach (Davidsson, 2005). Davidsson (2005) points to the existence of several process models in entrepreneurship, which states that given the fact that there are experimental process models inversely, it is believed that the use of these models depends on the context. He wondered if there was the best process. Via this question, he introduces two different models of the entrepreneurial process, the models presented by Bhave (1994) and Saras vathy (2001), arguing that most of the real-world processes are at the point between these two types of linear processes (Analytical and programmed) and emerging (creative and repetitive), and the superiority of one model to another depends on the proportion of the type of process and other key factors, i.e. the entrepreneur, the environment and the opportunity features or idea. Therefore, targeting an entrepreneurial process in the proper field, it provides a model of entrepreneurial components. The main point in this model is that there is no direct relationship between process and performance, nonetheless, the relative success of a process depends on its fitness with the entrepreneur, idea or opportunity and environment characteristics (Davidsson, 2005).

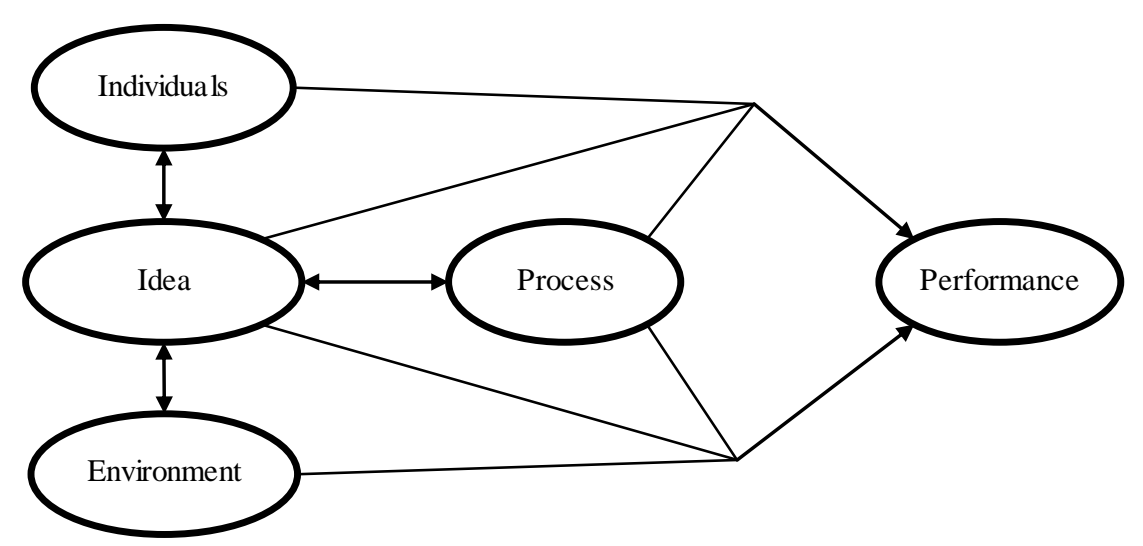

Figure 2. Entrepreneurial components (Davidsson, 2005)

Concerning the fitness between the entrepreneur and the idea and environment, literature points to the fact that entrepreneurs are looking for ideas that can use their own unique interests and skills in them, which is a central issue in resource-centered theory. This fitness is in accordance with the Impact Model (Sarasvathy, 2008), which begins with entrepreneurial resources. Also, the bricolage theory (Baker \& Nelson, 2005) emphasizes the use of available resources by an entrepreneur. For example, this fitness refers to the difference between experienced and novice entrepreneurs in choosing ideas. Experienced entrepreneurs are able to choose between intuitive, innovative and analytical decision-making methods in accordance with the degree of uncertainty associated with the idea, while novice entrepreneurs are not able to differentiate between different situations and thus similar methods are used for different situations with varying degrees of uncertainty. The ability of experienced entrepreneurs to adopt the decision-making method to the position enables them to choose any type of idea, while it is suggested to novice entrepreneurs to choose ideas that there is less uncertainty and analytical methods are suitable for this type of entrepreneurs (Davidsson, 2005).

\subsection{Source-driven Theory}

Penrose (1959) describes how the company's resources influence its growth, in which insufficient resources limit growth. Barney (1991) presented the principles of source-centered theory and developed it. He provided an accurate definition of resources and a complete set of features that transform a resource into a potential source of 
competitive advantage (value, scarcity, non-immutability, and non-interchangeability).

Alvarez and Busenitz (2001) described the use of resource-centric approach in entrepreneurship and examined the relationship between source-centered theory and entrepreneurship. They referred to heterogeneity as a common feature between two source-centered and entrepreneurial theories. But in source-centered theory, the focus is on resource heterogeneity, while entrepreneurship theory focuses on heterogeneity in the belief that there is resource value that enables entrepreneurs to transform homogeneous resources into heterogeneous outputs and have a better choice than others. The main question in the application of resource-centered theory in entrepreneurship is that of the source of heterogeneous sources of entrepreneurship. In this regard, Baker and Nelson (2005) use the concept of Bricolage (Lvi-Strauss, 1966) and according to Penrose's (1959) That companies may offer heterogeneous value based on seemingly homogeneous resources, a process model provides a process for the behavior of entrepreneurs in combining resources and adopting their own resource environment in Penrose's environment (Baker \& Nelson, 2005).

Wernerfelt (2011) has considered a process in which a company can home resources. He argued that current resources create asymmetry in competition for new sources. He argued that current resources create asymmetry in competition for new source (Wernerfelt, 2011). This argument is consistent with the first type of path dependence, which was proposed by Alvarez and Barney (2007) and referred explicitly to the theory of action since in the theory of action, entrepreneurs responded to the questions "Who am I? What I know and who I know. "And finally, the answer to the question" What can I do? "(Sarasvathy, 2008).

\subsection{Theory of Uncertainty}

Uncertainty is one of the fundamental concepts in most entrepreneurial theories (McMullan and Sheffield, 2006); in the creation Theory, for the decision to invest in an opportunity, the important consequences of this decision is not certain and the probability of these results when making a specific decision is unclear thus the entrepreneur faces a lack of trust (Knight, 1921) (Alvarez and Barney, 2007).

Many theories have conceptualized the role of uncertainty in entrepreneurial action to explain why an entrepreneur opted an opportunity. On this basis, two main trends emerged in the conception of uncertainty in entrepreneurship literature.

1. The first stream focuses on perceived uncertainty and seeks to differentiate between entrepreneurs and non-entrepreneurs based on differences in their knowledge. Therefore, uncertainty is considered as an obstacle to entrepreneurial action. In this context, there are some entrepreneurial entrepreneurs who know what to do and the distinction between entrepreneurs and non-entrepreneurs is that entrepreneurs know what they should do, that is, less understanding of uncertainty.

2. The second flow tends to endure uncertainty and sees the distinction between entrepreneurs and non-entrepreneurs in the difference between their motivation, their attitude and their willingness to take risks. Therefore, unwillingness to tolerate uncertainty is an obstacle to entrepreneurial action. In other words, entrepreneurship is not seen as the result of less understanding of uncertainty, but rather as a result of the desire to tolerate the uncertainty that everyone faces (Bauer et al., 2017).

Milliken (1987) distinguishes between three types of uncertainty faced by decision makers (McKelvie et al., 2011):

1. Situational uncertainty refers to situations in which actors do not have the ability to predict changes in the environment and understand the environment unpredictable. The question an actor faces in this uncertainty is, what is happening in the environment? Dynamics in an entrepreneurial environment leads to uncertainty of certainty that uncertainty in customer demand or technology is classic examples of it (McKelvie et al., 2011).

2. The effect of uncertainty, which is defined as the inability to predict the effect of future approval on the organization or the prediction of the effect of environmental changes on the organization. The question of an actor in this situation is what is the events influences on me in the environment?

3- The uncertainty of answer is defined as the lack of knowledge about response options or inability to predict the results of choosing a response. An important question in this uncertainty is what to do in this regard relating to external events?

Sarasvathy (2008), similar to Milliken (1987), identifies three types of uncertainty which entrepreneurs face:

1. The uncertainty of a statement in which its results and distribution are not known.

2. Objectives ambiguity where priorities are not clear. Even the entrepreneur himself does not know exactly what he wants. 
3. Isotropic uncertainty in which it is unclear what elements should be considered and ignored in the environment? For example, which elements of customer's feedback should be considered and what should be ignored. He knows the question of potential customers in the same way that we intend to determine the foods that are not consumed by examining the contents of a waste bin (Sarasvathy, 2008)

\subsection{Institutional Theory}

North (1990) defines institutions as human constraints that construct social, economic, and political interactions. From the perspective of North, institutions are designed by humans to establish order exchanges and reduce uncertainty. These constraints determine the cost of production and exchange, as a result of business start-ups, and the profitability and feasibility of economic activity (Veciana \& Urbano, 2008). Scott (1995) defines institutions in three categories of law (laws, regulations, and rules), normative (defines legitimate means for pursuing values), and cognition (refers to implied beliefs) (Scott, 1995), which provides incentives to direct or inhibit social behavior, such as entrepreneurial activity in an economy. The legal entities include government regulations and industrial agreements and standards that guide entrepreneurs' behavior by means of rules such as rules of play, supervision, and coercion. Normative institutions guide the behavior of entrepreneurs by defining what is right or expected in different business and social situations. These institutions include values (what is rightly considered) and norms (how things must be done according to values) that create rules for obedience. Cognitive institutions are rules and mental definitions that define the range of correct behaviors and beliefs (Stenholm et al., 2013).

There are three streams in the application of the theory of entrepreneurship (Bruton et al., 2010):

1. The first stream explores the impact of institutional conditions on entrepreneurship, in which the developed institutional environment fosters entrepreneurship and improves the inadequacy of the institutional environment of entrepreneurship. The lack of formal institutions or the lack of unofficial institutions to replace them, due to increased transaction costs, is a hindrance to entrepreneurship. Also, the existence of complicated and excessive regulations, which requires entrepreneurs to spend considerable time and money to meet the requirements, has the same result. Therefore, institutional environment is also effective not only on entreprene urial entry rates but also on the path to entrepreneurial actions (Bruton et al., 2010).

2. The second one is related to the relationship between legitimacy and entrepreneurship and addresses how entrepreneurs are seeking acceptability for their businesses. In other words, entrepreneurs have to take the desired behaviors of a given system in a social system because otherwise they will be sanctioned by deviating from accepted norms (Bruton et al., 2010).

3. The third stream deals with institutional entrepreneurship. Entrepreneurs work in areas that have not yet developed. Accordingly, DiMaggio (1988) argued that entrepreneurs may, alone or with the participation of others, build new institutions that help develop their field of activity or organization. So entrepreneurs may improve the environment as an entrepreneurial entity and create structures that help their business (Bruton et al., 2010). The concept of institutional entrepreneurship answers the question of how new institutions are developing and changing. Therefore, institutional entrepreneurship involves the activities of actors who have an interest in consolidation some institutions or those who use resources to create new institutions or change them (DiMaggio, 1988; Bruton et al., 2010).

\section{Theoretical Gaps} Under what conditions will the opportunity be created for discovery, or for the discovery opportunity of
creation?

A creation opportunity may turn into an opportunity for discovery, and vice versa. The conditions in which these transformations can take place requires extensive study. Of course, given that the discovery opportunities rooted in critical realism and creativity opportunities are rooted in evolutionary realism, the attempt to develop a single theory of both opportunities is like mixing water and oil, maybe They will be combined for a time, but will be re-detached again(Alvarez \& Barney, 2010).

\section{How can organizational and psychological processes be used to combine decision-making processes in terms of risk and uncertainty?}

The study of the formation of opportunity is a reminder that opportunities have a complex nature and have aspects of risk and uncertainty. For example, an entrepreneur may know enough about the likelihood of being able to fund the bank but not enough informed about how customers can respond to new product technology. The first aspect is the risk and the second one is uncertainty. In this case, the entrepreneur may be involved in both the process of creating and discovering the opportunity, but the probability that a single aspect of this process of 
forming opportunity involves both the mode of creation and the discovery of opportunity is low. However, entrepreneurs and others involved in the processes of creation and discovery simultaneously face an unmanageable challenge: how to apply two different decision-making approaches at the same time. Opportunity discovery includes a set of skills, such as data collection and analysis using risk-based decision-making tools. The creation of opportunity involves a different set of skills, such as intuitive, deductive, and repetitive decisions. Is a single decision maker, which can be involved in both the decision-making process simultaneously, a person or a company? For both the individual and the company, the combination of these skills involves a new type of two-sided power that cannot be simultaneously investigated and exploited (Tushman \& O'Reilly, 1996), but can simultaneously detect and create Slowly The psychological and organizational processes that make this type of dysfunctional are to be described (Alvarez et al., 2013).

\section{How the relationship between the micro level processes adopts the mood and the macro level process The} theory of evolution (change, selection, maintenance)

Weick (1979) observes that adoption at the individual level can lead to evolutionary processes at the organization level. Likewise, Ruef et al., (2003) observed that evolution at the organizational level includes a kind of adoption process at the individual level, as described by Weick (1979). The relationship between the process of adopting the creation and the evolutionary theory of entrepreneurship needs to be further developed. Although it seems that understanding the process of creating the opportunity may eventually approve the relationship between micro-level processes and macro-level processes of change, selection and maintenance of organizations (Alvarez \& Barney, 2010).

Appearing Companies created to exploit the opportunities of creating the first companies in a crowd. These organizations do not have existing stock companies for imitation, and therefore a challenge for the organization here is to establish it in a new form (McKelvey, 1982). Therefore, the perception of the emergence of a company that seeks to create and exploit a creation opportunity may differ from the perception of the emergence of a company to exploit a creative opportunity (Alvarez \& Barney, 2010).

\section{Application of creation Theory in Company Theory (Exchange Cost Theories and Defective Contract Theory)}

Although the level of analysis in the process of creating the opportunity is usually considered by the individual, business processes can, in fact, be considered at the level of the group, company or organization (Alvarez \& Barney, 2007). The study of the formation and exploitation of opportunities on the one hand and the theory of the company, on the other hand, are inter-related (Alvarez and Barney, 2005). Indeed, one way to form and exploit opportunities is to use a company, the hierarchical administration of the economy of exchange cost (Williamson, 1985) and the incomplete contract theory (Hart and Moore, 1988). These theories assume that the decision is about how to handle an exchange under risk conditions rather than uncertainty (Alvarez \& Barney, 2008). The exchange cost theory assumes that at the time of creating the company, the exchange parties can estimate the relative value of the investment to complete an exchange. Also, in the incomplete contract theory, it is assumed that one can estimate who has the most revenue from the exchange. Uncertainties do not exist (Alvarez and Barney, 2007). Therefore, the process of creating and exploiting opportunities is a significant challenge for the application of economic theory. Under the conditions of uncertainty, economic actors cannot understand, even in the probable way, how the opportunity arises, and as a result of the conditions of exploitation, and who will exchange the most benefits in exchange. In conditions of uncertainty, resources and capabilities must also be combined to form and exploit the opportunities of the people. When decision variables are considered by the economy of transaction costs and incomplete contract theory, it is unclear at the time of the decision how decisions about hierarchical management and the allocation of residual rights should be made?

In company behavioral theories, focusing on the origin, modification, and transfer of current organizational methods and focusing on organizational processes may be useful resources for theorizing for connecting the creation of the opportunity and the corporate theory. In other words, the emphasis is on how events and experiences turn into decision-making processes and routines decisions may be the best flow of research to understand the relationship between the opportunities and the companies that are used to exploit them. Alvarez and Barney (2005) refer to some of the possible tools that can be used to create and exploit creative opportunities. In general, when researchers begin to examine corporate theory questions in terms of decision-making in a state of uncertainty, research in the area of the process of creating opportunity creates a greater understanding of the conditions under which the various forms of exchange management, such as markets, Hierarchies and intermediate forms of administration are selected (Alvarez et al., 2013).

\section{Investigating the relationship between the creation of opportunity and organizational forms}

Traditionally, theories of the corporation have focused on the conditions under which those economic actors 
choose the hierarchical forms of management, that is, companies select the business to manage economic exchanges (Williamson, 1985). Companies have different entities. Research in organizational forms began with Burns and Stalker (1961). One of the factors that may affect organizational form is the formation and exploitation of opportunities whose impact is less understood. Factors affecting organizational forms include cases such as the corporate environment, the establishment team (Beckman, 2006), attempts to gain competitive advantage (Barney, 1991; 1986), institutional pressures (DiMaggio \& Powell, 1983) and social movements (Swaminathan and Wade, 2001). But the effect of forming and exploiting the opportunity is less understood. For example, companies created to exploit created opportunities may not be able to adapt to the forms of organization that prevailed in a pre-existing industry. Under conditions of creation, the organizers may choose their organizational form based on their personal experiences (Stinchcombe, 1965), or potentially select the forms of the industry in the field of new creation. Companies focus on learning and experimentation in this context, and choose the corporate commitment forms (Burton, 2001), family-centered (Ouchi, 1980) and Organic (Burns \& Stalker, 1961). The connection between opportunity and other forms of organization requires more attention. These questions require more experimental and theoretical analysis (Alvarez et al., 2013).

\section{How does the process of creating opportunity lead to a competitive advantage?}

It seems that creation processes to be the source of corporate advantage over discovery processes. Although this is a question that has not been asked yet and has not been answered. Because the information on the discovery process of information about creation processes is more accessible, it is likely that these advantages are temporary because the next actors imitate the successful actions of the previous entrepreneurs. In general, those exploiting discovery opportunities may have a sustainable competitive advantage, provided that their actions are protected by natural or accepted barriers). However, the processes of creation are dependent on the path and in which the creation of paths occurs, and if the opportunity is successfully formed and exploited, it can lead to unintended ambiguous advantages that result from learning experience through a unique action of an entrepreneur. This may make it harder for people to create opportunities for imitation (Barney, 1991). Since the processes of production have a significant output variance, the formation of creating opportunities has no basis to be used by entrepreneurs (Alvarez et al., 2013).

For the reasons given above, the difference between the formation and exploitation of discovery opportunities and creative opportunities may be a great experimental ground for testing some of the claims of a source-centered theory. Indeed, Opportunity Research may be one of the keys and unconfirmed assumptions of the source-driven theory. In particular, this theory assumes that resources and capabilities are distributed in a non-uniform way between actors, but does not explain how this heterogeneity comes from. Research in the process of opportunity refers to at least two sources of non-homogeneity:

(1) In a field of discovery, heterogeneity in resources and capabilities after the discovery and exploitation of opportunity may be due to previous differences in the consciousness of external shocks to the market or industry;

(2) In a context of creation, heterogeneity in resources and capabilities after the creation and exploitation of opportunities is due to an evolving vagrancy process that is unpredictable and dependent on the path through which the same actors are different. To the extent that exploratory opportunity can explain the source of differences in resources and capabilities, it may be able to complete strategic management research (Alvarez et al., 2015).

\section{Unanswered Questions (Alvarez \& Barney, 2007)}

Concerning the formation and exploitation of opportunities, there are questions that are more consistent with the creation theory, but have not been answered or asked at all (Alvarez \& Barney, 2007):

- How does entrepreneurial action create opportunities?

- Is the difference between entrepreneurs and non-entrepreneurs the cause or effect of entrepreneurial action?

- How do entrepreneurs use gradual, duplicate and inductive processes for decision-making?

Future research in entrepreneurship should carefully consider the information requirements that entrepreneurs act in (Alvarez \& Barney, 2007).

The usage of creation Theory to answer an unanswered question in source-centered theory

One of the important questions in resource-based theory is that from where the sources of heterogeneity that lead to competitive advantage come from (Barney, 2001), which has not yet been answered (Alvarez \& Barney, 2007). The creation Theory provides an answer to this question. Under the conditions of uncertainty, the adoption process over time has led to an exacerbation of very small differences at the beginning of the process of creating 
the opportunity. Therefore, the approval process can lead to heterogeneity in the resources and capabilities of valuable, scarce and costly imitation resources, thereby creating a sustainable competitive advantage. Because this process is different for individuals, teams, corporations, and organizations. The link between source-centered theory and creation theory refers to the role of path dependence (Arthur, 1989). The path dependence in the theory of creativity is of two types. The first type of path dependence refers to the fact that the opportunities determined by the entrepreneur relate to knowledge and information that has already existed in a previously established pathway and affects the actions of the entrepreneur. In the second type of path dependence, the entrepreneurial action is not only influenced by an existing path, but it can also create that route. The second-order dependence of the second-generation theory is related to researchers, who consider the initial condition as an initial design that determines the original shape of a company and its following development (Nelson and Winter, 1982). Creation theory points to the fact that the preliminary conditions of the company may be the result of the actions that entrepreneurs have taken to create the opportunity (Alvarez \& Barney, 2007).

\section{Changing in actors for the creation of opportunity}

The process of creating the opportunity changes the actors involved in the process (Alvarez and Barney, 2010), but there is still no empirical research to test this conjecture.

\section{Discussion and Conclusion}

Technology entrepreneurship classifies the entrepreneurial opportunities of the technology-driven by identifying, determining, or creating and exploiting those opportunities. It also involves managing small businesses owned by engineers and scientists, introducing applications for a specific technology, starting new technology-centric businesses, introducing new applications, or manipulating opportunities that all rely on scientific and technical knowledge Besides working with others to create technology or technology change.

Technology-based micro-enterprise through research and development, technology creation, technological opportunities, technology transfer, and technology management lead to the creation of technology-based companies and technological innovation in existing organizations. According to statistics provided by the GEM Center, the Innovation Entrepreneurship Indicator, which represents the emerging and new entrepreneurial entrepreneurship TEA, $12.3 \%$ of new enterprises occur in the adult population (18-64 years old). The "Understanding the Entrepreneurial Opportunity" indicator, which indicates an individual's perceived opportunities for the environment around him in the next 6 months, is 36.9 percent in 2016, which is ranked 40th among 67 countries (Global Entrepreneurship Center Report, 2016).

One of the typical methods of companies to decide future trends is R \& D activities. Among the most important factors in the failure of research and development plans are mistakes in initial estimates, uncertainty in estimates and performance, external factors changes, and, eventually, the complexity and extent of the project scope. The notion of creating is an opportunity to outline the actions that entrepreneurs take to shape and exploit opportunities (Sarasvathy et al., 2003).

Mentality opportunities deliver opportunities where none of the parties have a clear and distinct supply and demand, then one or both of them must be created and several economic patents must be made in the way of marketing, franchising, etc., so that opportunity can be created. This perception of opportunity deals with the creation of new markets (Saras vathy, 2003).

Based on the research carried out by various thinkers, the process of the emergence of opportunity is not fully understood and requires further research. The aspects of the creation Theory are described by a group of writers (Ruef et al., 2003; Alvarez and Barney, 2007; Baker and Nelson, 2005; Saras vathy, 2003; Sarasvathy, 2001). Nevertheless, creation theory still needs to be elaborated as a coherent theory in literature. Faced with everyday problems, it is easy to understand processes and events that lead to the emergence of opportunities It is comprehensible to understand the processes through being with them and living with them, but in technological matters, since this is not possible for us, we can rely on the information of individuals and organizations that have encountered these issues, and create technological entrepreneurship opportunities in addition to use measuring and identify research variables, questionnaires and standard questions developed and industrialized by other researchers (Nelson, 2005; Sarasvathy, 2001; Weick, 1979).

Therefore, in the present study, the gap between theories was discussed and it turns out to be clear that in some cases there are questions that need to be addressed to develop theories.

\section{References}

Alimadadi, S., Bengtson, A., \& Hadjikhani, A. (2018). How does uncertainty impact opportunity development in internationalization? International Business Review, 27(1), 161-172. 
https://doi.org/10.1016/j.ibusrev.2017.06.002

Alvarez, S. A., \& Barney, J. B. (2005). How do entrepreneurs organize firms under conditions of uncertainty? Journal of management, 31(5), 776-793. https://doi.org/10.1177/0149206305279486

Alvarez, S. A., \& Barney, J. B. (2007). Discovery and creation: Alternative theories of entrepreneurial action. Strategic entrepreneurship journal, 1(1-2), 11-26. https://doi.org/10.1002/sej.4

Alvarez, S. A., \& Barney, J. B. (2008). Opportunities, organizations, and entrepreneurship. Strategic Entrepreneurship Journal, 2(4), 265. https://doi.org/10.1002/sej.61

Alvarez, S. A., \& Barney, J. B. (2010). Entrepreneurship and epistemology: The philosophical underpinnings of the study of entrepreneurial opportunities. Academy of Management annals,4(1), 557-583. https://doi.org/10.1080/19416520.2010.495521

Alvarez, S. A., \& Busenitz, L. W. (2001). The entrepreneurship of resource-based theory. Journal of management, 27(6), 755-775. https://doi.org/10.1177/014920630102700609

Alvarez, S. A., Barney, J. B., \& Anderson, P. (2013). Forming and exploiting opportunities: The implications of discovery and creation processes for entrepreneurial and organizational research. Organization Science, 24(1), 301-317. https://doi.org/10.1287/orsc.1110.0727

Alvarez, S. A., Young, S. L., \& Woolley, J. L. (2015). Opportunities and institutions: A co-creation story of the king crab industry. Journal of Business Venturing, 30(1), 95-112. https://doi.org/10.1016/j.jbusvent.2014.07.011

Arthur, W. B. (1989). Competing technologies, increasing returns, and lock-in by historical events. The economic journal, 99(394), 116-131. https://doi.org/10.2307/2234208

Baker, T., \& Nelson, R. E. (2005). Creating something from nothing: Resource construction through entrepreneurial bricolage. Administrative science quarterly, 50(3), 329-366. https://doi.org/10.2189/asqu.2005.50.3.329

Barney, J. (1991). Firm resources and sustained competitive advantage. Journal of management, 17(1), 99-120. https://doi.org/10.1177/014920639101700108

Bauer, D. M., Bell, K. P., Nelson, E. J., \& Calhoun, A. J. (2017). Managing small natural features: A synthesis of economic issues and Emergence opportunities. Biological Conservation. https://doi.org/10.1016/j.biocon.2017.01.001

Beckman, C. M. (2006). The influence of founding team company affiliations on firm behavior. Academy of Management Journal, 49(4), 741-758. https://doi.org/10.5465/AMJ.2006.22083030

Bhave, M. P. (1994). A process model of entrepreneurial venture creation. Journal of business venturing, 9(3), 223-242. https://doi.org/10.1016/0883-9026(94)90031-0

Bruton, G. D., Ahlstrom, D., \& Li, H. L. (2010). Institutional theory and entrepreneurship: where are we now and where do we need to move in the future?. Entrepreneurship theory and practice, 34(3), 421-440. https://doi.org/10.1111/j.1540-6520.2010.00390.x

Burns, Tom E. and Stalker, G.M. (1961). The Management of Innovation. University of Illinois at Urbana-Champaign's Academy for Entrepreneurial Leadership Historical Research Reference in Entrepreneurship.

Burton, M. D., ed. (2001). The Company They Keep: Founders'Models for Organizing New Firms. Stanford University Press, Stanford, CA.

Davidsson, P. (2005). The entrepreneurial process as a matching problem.

DiMaggio, P. (1988). Interest and agency in institutional theory. Institutional Patterns and Organizations Cambridge, 1-21.

DiMaggio, P., \& Powell, W. W. (1983). The iron cage revisited: Collective rationality and institutional isomorphism in organizational fields. American Sociological Review, 48(2), 147-160. https://doi.org/10.2307/2095101

Global Entrepreneurship Center Report, 2016

Hart, O., \& Moore, J. (1988). Incomplete contracts and renegotiation. Econometrica: Journal of the Econometric Society, 755-785. https://doi.org/10.2307/1912698 
Knight, F. H. (1921). Risk, uncertainty and profit. New York: Hart, Schaffner and Marx.

Lvi-Strauss, C. (1966). The savage mind. University of Chicago Press.

McKelvey, B. (1982). Organizational systematics: Taxonomy, evolution, classification. Berkeley: University of California Press.

McKelvie, A., Haynie, J. M., \& Gustavsson, V. (2011). Unpacking the uncertainty construct: Implications for entrepreneurial action. Journal of Business Venturing, 26(3), 273-292. https://doi.org/10.1016/j.jbusvent.2009.10.004

Milliken, F. J. (1987). Three types of perceived uncertainty about the environment: State, effect, and response uncertainty. Academy of Management review, 12(1), 133-143.

Nelson R. R., \& Winter S. G. (1982). An evolutionary theory of economic change. Harvard Business School Press, Cambridge. https://doi.org/10.1017/CBO9780511808678

North, D. C. (1990). Institutions, institutional change and economic performance. Cambridge: Cambridge University Press.

Ouchi, W. G. (1980). Markets, bureaucracies, and clans. Administrative science quarterly, 129-141. https://doi.org/10.2307/2392231

Penrose, E. T. (1959). The theory of the growth ofthe firm. New York: Sharpe.

Ruef, M., Aldrich, H. E., \& Carter, N. M. (2003). The structure of founding teams: Homophily, strong ties, and isolation among US entrepreneurs. American sociological review, 195-222. https://doi.org/10.2307/1519766

Sarasvathy, S. D. (2001). Causation and effectuation: Toward a theoretical shift from economic inevitability to entrepreneurial contingency. Academy of management Review, 26(2), 243-263.

Sarasvathy, S. D. (2008). Effectuation: Elements of entrepreneurial expertise. Edward Elgar Publishing. https://doi.org/10.4337/9781848440197

Sarasvathy, S. D., Dew, N., Velamuri, S. R., \& Venkataraman, S. (2003). Three views of entrepreneurial opportunity. In Handbook of entrepreneurship research (pp. 141-160). Springer US.

Stenholm, P., Acs, Z. J., \& Wuebker, R. (2013). Exploring country-level institutional arrangements on the rate and type of entrepreneurial activity. Journal of Business Venturing, 28(1), 176-193. https://doi.org/10.1016/j.jbusvent.2011.11.002

Stinchcombe, A. L. (1965). Organizations and social structure. Handbook of organizations, 44(2), 142-193.

Swaminathan, A., \& Wade, J. B. (2001). Social movement theory and the evolution of new organizational forms. The entrepreneurship dynamic in industry evolution, 286-313.

Tushman, M. L., \& O'Reilly III, C. A. (1996). Ambidextrous organizations: Managing evolutionary and revolutionary change. California management review, 38(4), 8-29. https://doi.org/10.2307/41165852

Veciana, J. M., \& Urbano, D. (2008). The institutional approach to entrepreneurship research. Introduction.

Weick, K. (1979). The social psychology of organisations. Reading, Mass: Addison-Westly.

Weick, K. E. (1977). Enactment processes in organizations. New directions in organizational behavior, 267, 300.

Weick, K. E. (1995). Sensemaking in organizations (Vol. 3). Sage.

Wernerfelt, B. (2011). Invited editorial: The use of resources in resource acquisition. Journal of Management, 37(5), 1369-1373. https://doi.org/10.1177/0149206310371693

Williamson, O. E. (1988). Technology and transaction cost economics: a reply. Journal of Economic Behavior \& Organization, 10(3), 355-363. https://doi.org/10.1016/0167-2681(88)90055-8

Wood, M. S., \& McKinley, W. (2010). The production of entrepreneurial opportunity: a constructivist perspective. Strategic Entrepreneurship Journal, 4(1), 66-84. https://doi.org/10.1002/sej.83

\section{Copyrights}

Copyright for this article is retained by the author(s), with first publication rights granted to the journal.

This is an open-access article distributed under the terms and conditions of the Creative Commons Attribution license (http://creativecommons.org/licenses/by/4.0/). 